\title{
Historical settlement of Vologda: historical and cultural landscape and three-dimensional and spatial structure of the city
}

\author{
Elena M. Nikitina ${ }^{1}$ \\ ${ }^{1}$ Vologda State University, Lenina Street 15, Vologda, 160000, Russia
}

\begin{abstract}
The article presents a comprehensive study of the city-forming significance of historical and cultural landscape in the three-dimensional and spatial composition and silhouette of Vologda. Particular attention is paid to the analysis of influence of the natural landscape components on the planning structure, the role of morphology of historical buildings for the perception of panoramas and views, including St. Sophia Cathedral, the cathedral bell tower and other city dominants.
\end{abstract}

\section{Introduction}

"The historical and cultural landscape is a historically developed natural and cultural territorial complex that has retained authentic (natural, material, mental) features and is recognized by modern society as an object of cultural and natural heritage. It is a part of the cultural landscape, i.e. a constantly developing natural and cultural structure formed as a result of continuous interaction of nature and man." (Museum Dictionary, http://www.museum.ru/rme/dictionary.asp?69)

In 2012, the Federal Law "On Objects of Cultural Heritage (Historical and Cultural Monuments) of the Peoples of the Russian Federation", No. 73-FZ, was amended, which for the first time in Russian legislation formulated definitions of protection subject for historical settlements. This formalizes the idea of a city as a holistic entity that has a "three-dimensional and spatial structure and its elements", a "composition and silhouette of buildings"; "compositional-scenic relationships (panoramas), the ratio of natural and manmade environment" protected by law [1, Art. 59].

Now, protection of individual objects of cultural heritage with their surrounding architectural and historical environment is coupled with planning and three-dimensional and spatial composition of the city as a whole, historically valuable scenic views and silhouette composition. Thus, the urban planning heritage and all its basic city-forming components are recognized as valuable. The city should not be considered as an accumulation of separate objects, but it should be perceived as an integrated organism, which allows one to identify and consolidate the three-dimensional composition of the settlement, which was formed in certain natural and geographical conditions.

The historical and cultural landscape should be defined not as a geographical term, but as an object of heritage. When exploring the territory of a historical settlement, it is much more important to identify changes and core values that the natural landscape has acquired over time, in the past, to determine its role in forming the historical and cultural heritage of the city.

So, the historical and cultural landscape is a natural landscape, transformed by the creative influence of people who inhabit it, which is an essential part of historical and cultural heritage.

\section{Research methodology}

The author, being a member of the project team, carried out a comprehensive, multi-layer analysis of the threedimensional and spatial structure of the city as part of research work on development of the "Project of the territory boundaries and protection subject of Vologda as the historical settlement of regional significance". The following were taken into account:

- Features of the natural landscape;

- A system of high-rise dominants and their relationship with the background development;

- Spatial-scenic framework of the city, i.e. a system of visual connections of architectural high-rise dominants;

- The specifics and form-making elements of city panoramas.

First of all, cartographic studies were carried out to identify valuable scenic disclosures of city panoramas and views, subjected to protection. Bibliographic sources, historical, topographic maps of Vologda, plans for the protection zone projects of 1988 and 2009 were studied.

During full-scale urban planning studies, the main factors that determine the features of the spatial structure of the city were established. During visual landscape analysis, detailed photographic fixations were carried out, and in exceptional cases the "step-by-step shooting" was used. The form-making elements of scenic views (dominants, background buildings, elements of natural and artificial landscape) and their most important characteristics were studied.

\footnotetext{
* Corresponding author: Makarovayulia169@mail.ru
} 

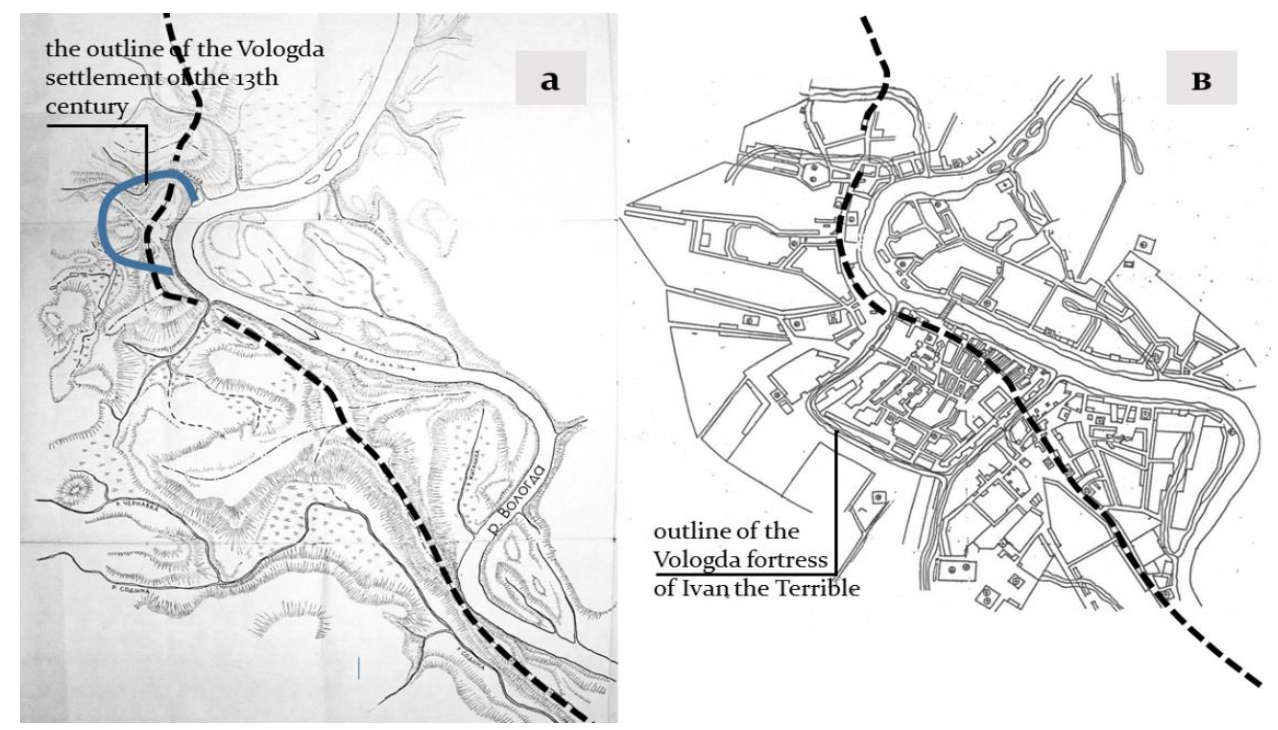

Fig. 1. The role of relief in the structure of the city: a) The main route of the elevated ridge of the indigenous right bank of the Vologda River on the scheme of reconstruction of paleolandscape by Sharov S. (dashed line); b) Combination of the elevated ridge route with the layout of Vologda on the plan of 1770, where the outlines of fortress are fixed.

\section{Natural landscape as the initial city- forming factor}

The Russian cities, and Vologda, in particular, are characterized by the landscape principle of the urban structure planning. As a rule the Russian settlements were developed along rivers, which are the most important natural factor for the historical city. The first buildings were created at well-protected, elevated banks in the river bend. So, the relief and water bodies, river channel, tributaries, ravines are the most important cityforming natural factors that affect the existing planning structure of the city. But the natural landscape (the beauty of revealing landscapes, the picturesque panoramas) also had to meet the aesthetic preferences of the Russians. "The position of cathedrals and the growth trends of city were largely determined by the landscape features of the territory being developed. The specificity of the natural environment has always played a decisive role in the formation of ancient Russian cities. The cities laid on high banks of rivers were built depending on the outline of the rivers and streams and their structure corresponded to the local topography" [2].
The urban landscape with its natural and artificial components is the most important element of the threedimensional and spatial composition of the city. Natural components (landscape): relief, river water areas, landscaping, form the features of the artificial components of the urban environment, i.e. man-made buildings and constructions, planning structure of streets and squares, etc.

Assessing the role of natural landscape as the cityforming one in the composition of Vologda, one should turn to the history of the settlement. The Vologda settlement appeared in the 13th century at the intersection of roads connecting the Novgorod Republic with the northeastern principalities [3]. The high bank of the Vologda River with influx of the Khrulev Stream (Fig. 1, a) was a strategically advantageous and convenient location for construction. Even now the most expressive panoramas of the modern city are revealed from here (Lenivyi Torg) (Fig. 2).

Further, the city was actively developed to the southeast direction - to Moscow. In the XV century, the length of the city along the Vologda River was at least 2 $\mathrm{km}[4]$.

In 1565-1566, Ivan the Terrible began to build a new fortress on the highest site on the right bank of the

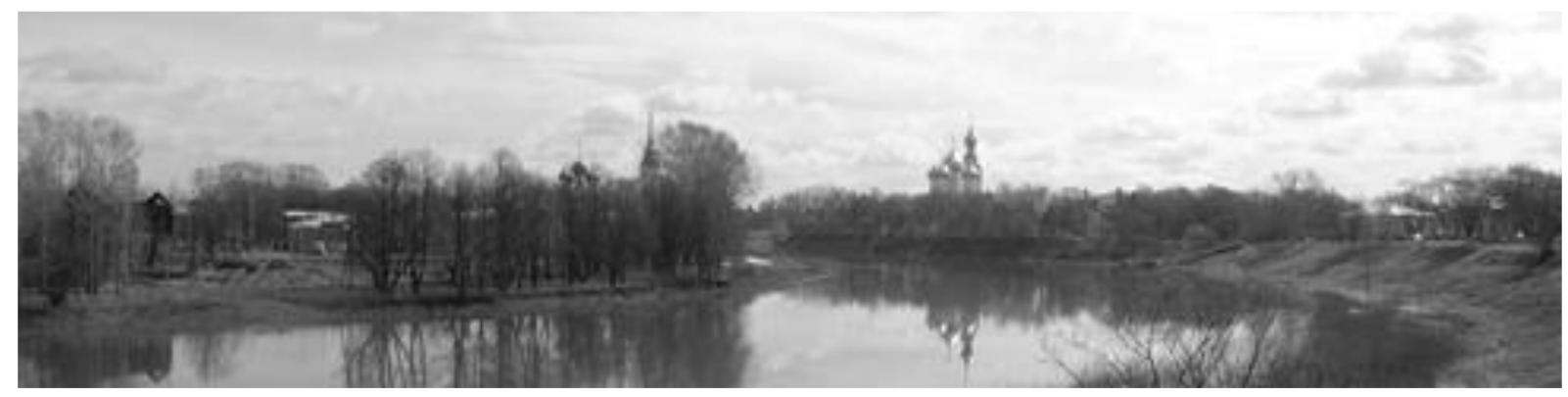

Fig. 2. Panoramic disclosure of the river from the Lenivyi Torg. 
Vologda River, surrounded by natural depressions rivers, streams, ravines. Ambitious earthworks to straighten and deepen were carried out, thus maximizing the advantages of natural landscape (Fig. 1, b). Here in 1568, Ivan the Terrible laid the first stone church in Vologda - St. Sophia Cathedral [5]. The waterway along the river and the land tracts (to Moscow, to the north - to Beloozero and Arkhangelsk, to the south - to Poshekhonye) were oriented to Sobornaya Gorka.

In 1781 after the approval of the Catherine's "Regular Plan for the Provincial City of Vologda", chaotic medieval buildings were replaced by a clear network of rectangular neighborhoods, but the majority of dominants retained their urban development significance, closing the most important street perspectives. According to this plan, Vologda developed until almost the 20 s of the XX century. When comparing historical maps with the current situation, it was determined that in the area of Burmaginykh, Lugovaya, Zavrazhskaya, Dovratskaya streets (on the territory of the Vologda settlement), a pre-regular layout was preserved. The ancient directions of streets can be seen in the 54th district, surrounded by S. Orlov str., Pobedy Avenue, Torgovaya and Kremlevskaya Squares.

When drawing up the first general plan of the city, the designers of the XVIII century took into account the existing natural and urban planning situation. The Vologda Kremlin was inscribed into the new grid of streets and became the center of urban planning composition, which included the ancient fortress and the Bishop's court. The Kremlin existed until the first decades of the 19th century, when the northwestern and southwestern ramparts were filled. But the outlines of the Vologda fortress of Ivan the Terrible were preserved in the historical and cultural landscape of the modern city in the form of boulevards along Mira str., Oktyabrskaya str. and Pobedy Avenue.

\subsection{The role of relief in the three-dimensional and spatial composition of Vologda}

The three-dimensional and spatial composition of the city was historically developed in direct dependence on the specifics of the relief. The paleolandscape reconstruction of the city central part is of key importance for understanding the compositional structure and silhouette of Vologda. Its reconstruction was carried out by S.A. Sharov in the framework of preparation of historical and architectural plan of Vologda in 1988 (Fig. 1, a) [6].

The key role in formation of the modern relief in the Vologda River basin was played by the ancient preglacial relief, i.e. protrusions of bedrock [6]. Pronounced extended ridge of the root right bank of the Vologda River crosses the city from north-west to southeast, in the direction of the modern Burmaginykh str. (in the territory of the Verhniy Posad); S. Orlov str. (within the boundaries of the former fortress of Ivan the Terrible), Sovetsky Avenue, which coincides with the Moscow land highway.

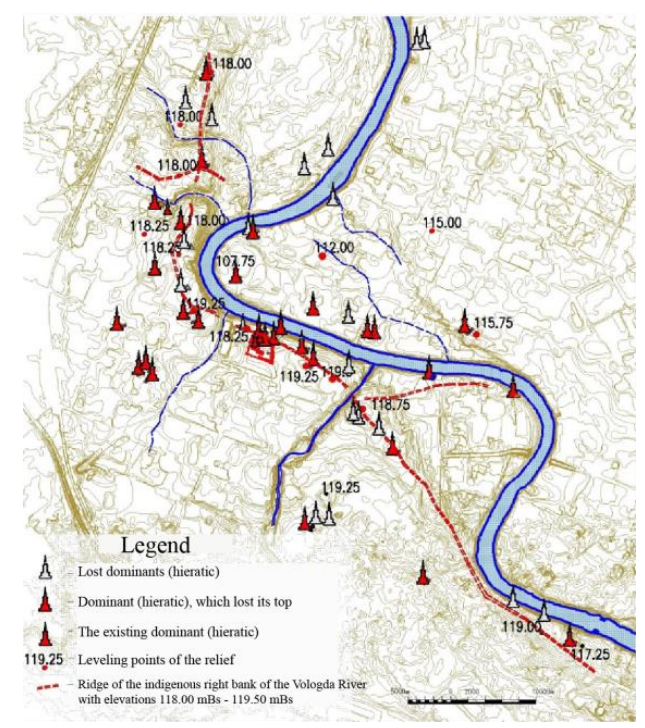

Fig. 3. Correlations between the city relief and location of high-rise dominants.

To adjust field surveys of three-dimensional and spatial structure of the city, the author carried out a cartographic study: the paleorelief scheme (according to A.S. Sharov), the modern topographic subbase and a layout of all existing and lost churches were combined (Fig. 1. a, b). It was found that the most significant urban dominants (the verticals of bell towers and churches) were concentrated (Fig. 3) exactly here, on this elevated riverbed ridge at $118.00 \mathrm{mBs}-119.50 \mathrm{mBs}$ (Baltic height system). The embankment of the opposite floodplain coast of Vologda are 10-13 meters lower. Here, on Navolok, almost all the churches built in the

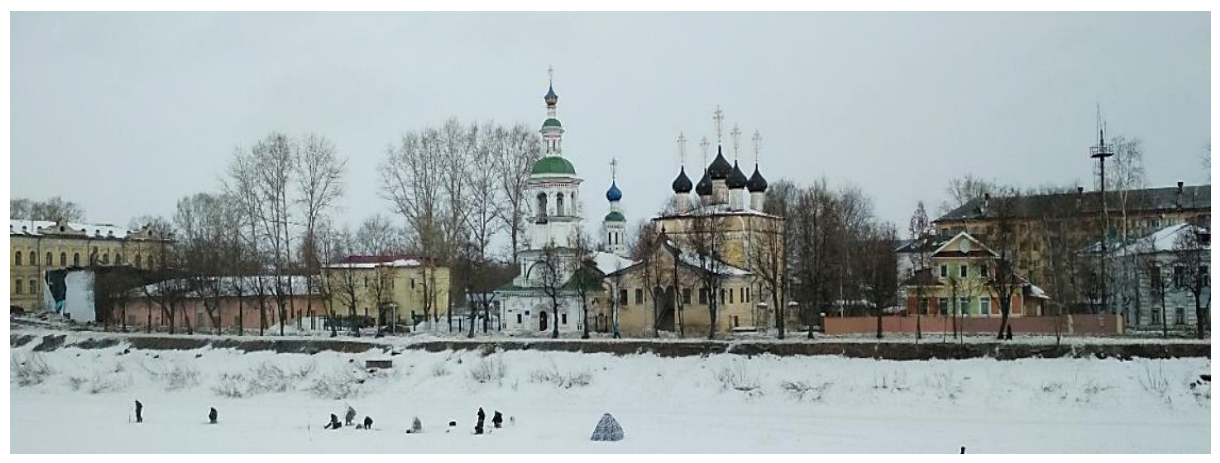

Fig. 4. Fragment of a panorama of the embankment of the 6th Army. 


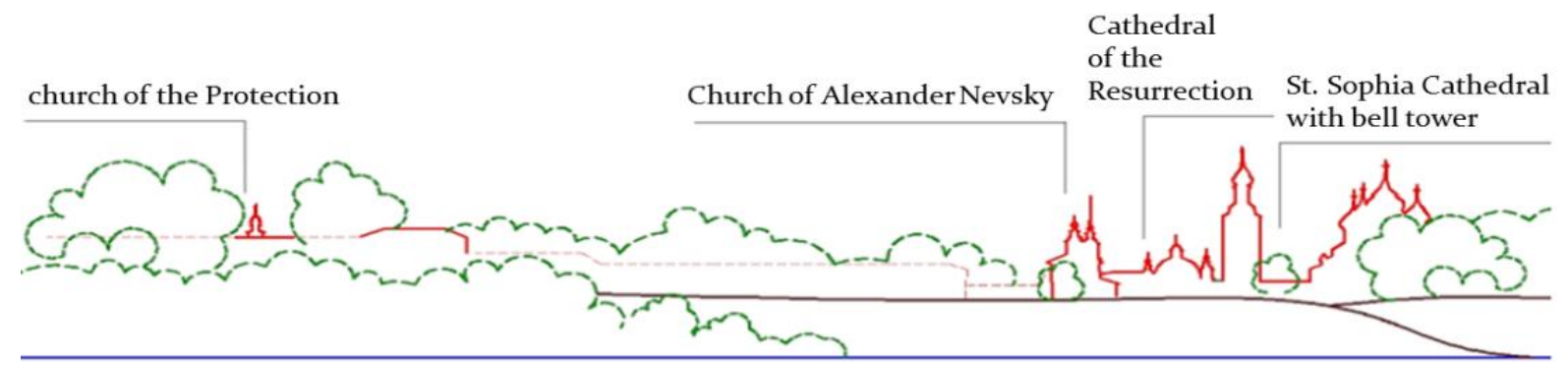

Fig. 5. Scheme of protected panoramic view for the ensemble of the Vologda Kremlin from the Church of John Chrysostom on the embankment of the 6th Army.

17th-18th centuries are located on the coast, along the embankment of the 6th Army (Fig. 4). These features of the dominant placement form the spatial framework of the city.

Cathedrals that concentrated along the ridge, even having small size, actively participated in the formation of panoramas due to the compositionally active relief. The monumental St. Sophia Cathedral with a 78-meter bell tower, the pointed spiers of the Baroque bell towers gave special dynamics to the panorama silhouette of the right bank of the river (Fig. 5). This is the bell tower of the church of Zosima and Savvatiy Solovetsky, the church of Alexander Nevsky, the church of Varlaam Khutynsky, on the bell tower of St. Nicholas Church on the Zolotye Kresty mountain now there is no top. The Cathedral of Christ Resurrection (on Lenivyi Torg) and the Cathedral of Transfiguration of Jesus (in the Boloto) were destroyed in Soviet times. The white-stone tents of distant churches - Lazarevskaya, the Assumption of the Blessed Virgin Mary of the Assumption Monastery, Trinity-Gerasimov (also lost in the 30s) were included in the panorama. These verticals, due to their size, location at high elevations of the ridge and low, 1-2-story background buildings of the XIX century, also fit into the panorama of the right bank of the Vologda River and participated in formation of expressive threedimensional city structure.

\subsection{The water area of the Vologda River as the main axis of the spatial composition}

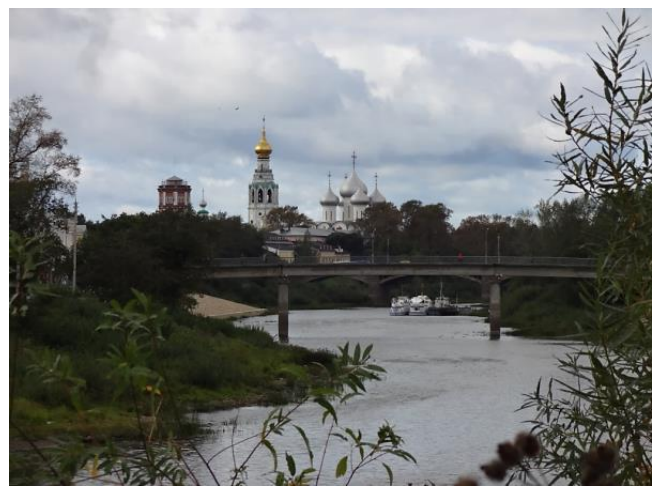

Fig. 6. The water area of the Vologda River is the main axis of the city spatial composition.

The general composition of the historical center of Vologda is based on the interaction of water bodies with a system of architectural ensembles. The main factor determining the silhouette organization of the city center is the presence of the Vologda River, and the artificially created Zolotukha River at its borders. Almost all other numerous streams and small rivers were filled, put into pipes or dried up. In the XIX century ditches Perekop and Bolshoy Perekop excavated for construction of the Ivan the Terrible fortress disappeared. Zolotukha, being a part of the fortress ditch, was preserved, as it was used to deliver goods to warehouses of Gostinodvorskaya Square trading shops.

The water area of the Vologda River has become the main axis of the spatial composition of the city (Fig. 6). The most valuable are the panoramas and views from embankments: the picturesque bends of the Vologda River form a complex system of scenic views. Within the city boundaries, the river has several dynamic turns that influenced the perception system of city panoramas and determined compositional techniques, the placement of vertical dominants and accents. Each turn is marked by a church or cathedral ensemble. All elements of the silhouette composition are perceived from different angles, in various combinations with each other, with green slopes of embankments, and this creates a valuable, unique in beauty, historical and cultural landscape.

High dominants either concentrate, stacking on top of each other in certain nodes, creating rich silhouette compositions (Fig. 8), or break up into separate components. When moving along the river, one can see this group from a different angle and with new verticals. There is a constant change of rhythms, contrasts, impressions: the rhythm of vertical dominants on the embankment of the 6th Army (Candlemas Church, John Chrysostom Church, two cathedrals in the name of Dmitry Prilutsky, St. Nicholas Church in Vladychnaya Sloboda) is combined with a pitch of 350-550 $\mathrm{m}$ with the rhythm of dotted development of low-rise buildings, emphasizing their dominant importance. In Zarechye, almost all churches, except cemetery ones, are located on the embankment, they were built at the crossings and bridges [2]. St. Nicholas Church in Vladychnaya Sloboda is located deeper, but 3-4 meters higher than the coastal churches, and its powerful domes are also actively involved in the panorama.

The whole composition is crowned with a powerful panorama of the Spaso-Prilutsky Monastery, without losing visual and spiritual connection with the main 


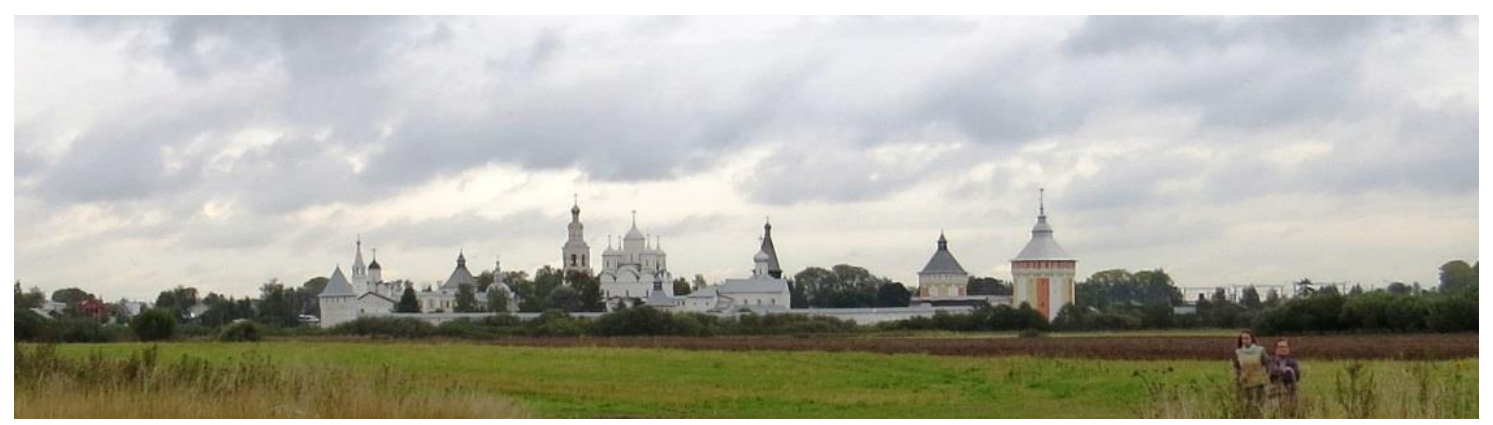

Fig. 7. Panorama of the Spaso-Prilutsky Monastery from the wet meadow.

cathedral city ensemble: from the walls of the monastery one can see the head of the bell tower of St. Sophia Cathedral. For visitors from the northern direction the city "begins" from the Spaso-Prilutsky Monastery (Fig. 9).

\section{Features of urban planning composition of historical settlement of Vologda}

The three-dimensional and spatial structure of the city is determined by the ratio of dominants and background development. The city of Vologda is characterized by the silhouette of riverine panoramas with the dominance of cathedrals and their bell towers over low-rise surroundings. The height of this background development for areas, which preserved the historical appearance of the 19th century, is mostly the height of a wooden city house, up to about $8 \mathrm{~m}$ from the sidewalk to the eaves. The top of churches with bell towers, which had different heights $(30-78 \mathrm{~m})$ and served as compositional dominants of various levels (from citywide to local) dominated above the building massif.

\subsection{The role of high-rise dominants in the city composition}

The role of dominants is also determined by their leading role in formation of ensembles of streets, squares, embankments and compositional nodes, as well as in completion of visual directions. St. Sophia Cathedral with a bell tower dominates the entire city, creating panoramas with great power of artistic influence (Fig. 8). Churches with their expressive silhouettes are the most important form-making elements of panoramas. As in all Russian cities, the verticals of cathedrals and bell towers served as important landmarks on the waterway and in the confusion of medieval streets. Their significance is especially important for a city with a calm relief and for this reason they are of particular vulnerability of its silhouette organization. After loss of a significant part of the churches, the silhouette of the city changed.
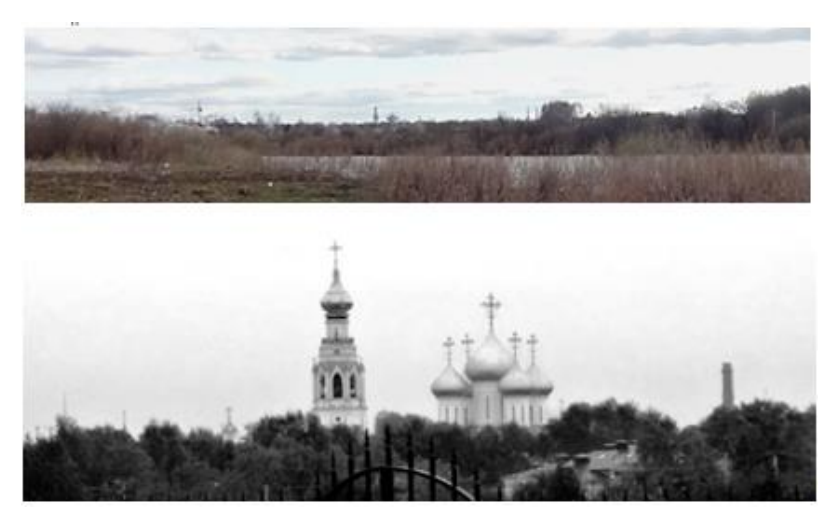

Fig. 8. View of the historical part of the city from Chernyshevsky str., 133. General view of the panorama, fragment.

Due to the Catherine redevelopment of 1781, part of the church ensembles was closed inside the district territory. These included the ensemble of the SpasoKamensky Holy Spirit (former male) monastery, Elena and Konstantin Church, Vladimir Churches, Antipyevskaya Church, which partially lost their urban importance.

To maintain the quality of the city composition, it is necessary to restore silhouette-forming objects: the spireshaped completion of the bell tower and the head of St. Nicholas Church on the Zolotye Kresty, the church of Zosima and Savvatiy Solovetsky, preferably to reconstruct dominants with undeveloped territories.

\subsection{Historical buildings of Vologda: the principle of "transparency"}

The features of city planning and development are another important city-forming factor. Vologda was historically wooden, which required the presence of fire breaks between the houses, so the dashed, perimetershaped system of buildings developed. And this ensures visibility, "transparency" of city, a complex end-to-end system of visual connections - church domes, spiers of bell towers are visible from the inside of the blocks (Fig. 9).

Even at the beginning of the 20th century, the city consisted mainly of blocks of wooden manor buildings with gardens and vegetable gardens in the depths of plots. These were 1-2-story buildings, several two-story 


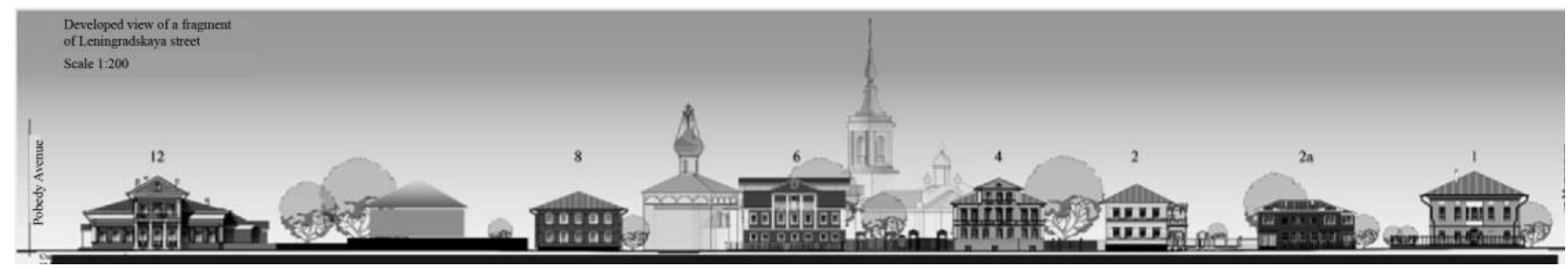

Fig. 9. Discrete with distances type of building development. Developed view of a fragment of Leningradskaya str. Dominant churches are visible between the houses.

houses with a mezzanine also remained. Most of the wooden houses on the territory of Vologda belong to the end of the 19th - beginning of the 20th centuries. Building was perimetral, carrier out along the streets, with clear spaces, the houses were separated from each other, which was prescribed by the "city law" in the 15th century, according to fire protection requirements. It was important that one house did not intercept another; in such a sparse planning structure between the houses, churches on the neighboring streets were visible, and between the streets there were gardens and meadows. Such a structure has been partially preserved at present in the territories of the Verhniy Posad in the area of Mayakovsky, Burmaginyh and Zarechie streets, behind the stone buildings on the left embankment - in particular, west of Chernyshevsky street in the area of Gogol, Gorky and Nekrasov streets.

Historically established distances between wooden houses do not always meet modern fire safety requirements. For example, for houses on Kremlin Square, these distances range from $6.5 \mathrm{~m}$ to $10 \mathrm{~m}$, on Torgovaya Square, the distance between houses No. 9, No. 11 is slightly more than $5 \mathrm{~m}$. The distances of $9 \mathrm{~m}, 8$ $\mathrm{m}$ are common for Blagoveshchenskaya str. In the Zarechnaya part, where the buildings are located more thinned, the distance between the houses is from $6.5 \mathrm{~m}$. As a rule, the distance between the buildings is less than the dimensions of facades forming the street. The spatial structure of streets is characterized by orientation of streets toward dominants, the buildings volumes are orientated perpendicular to the streets, the wooden fences are located along the lines of street facades, the roofs are configured with a hip along the main facade, the slope of roofs is within $26^{\circ}$.

Until the 20th century, the Vologda River was navigable and served as the main transport artery, the most important compositional axis in the planning frame, and therefore it was the front face of the city. Stone mansions, public buildings and beautiful cathedrals were built on its embankments in the city center. These building lines have the same morphotype - discrete, with distances, which is characteristic for historical part of the city. The river was not cut off from it, all the streets converged to the embankments.

Stone buildings, both public and residential, were concentrated mainly in the city center. The stone building with a "continuous facade" in Vologda is represented by only a few fragments: on the former Gostinodvorskaya street and Gostinodvorskaya Square (now Pobedy Avenue and Mira str.); on Stone Bridge,
Vozrozhdeniya Square (former Afanasyevskaya Square) and on Lenin str. (former Kirillovskaya).

It is very important to maintain the historical rhythm of the district building development (discrete, with "distances"), and the intervals in the street front of development, at which intra-district dominants can be constantly observed. The type of new buildings that are actively used in the city - twin, connected by transitions (blocked) prevents this. It should be taken into account when designing such buildings and the potential possibility for destruction of visual connections should be precluded. At the same time, it is necessary to adhere not only the high-rise regulated grades of eaves and roof skates, but also the facade length along the street, characteristic for specific districts of the city.

\section{Conclusions}

Comprehensive scientific studies of the Vologda territory, conducted in 2016-2017, allowed us to draw positive conclusions about the qualities of the threedimensional and spatial structure of the historical settlement. When studying the historical and cultural landscape of Vologda as a historical settlement of regional significance, we took into account the specifics of the natural landscape components, the system of highrise dominants and their relationship with the surrounding low-rise buildings, the uniqueness of the three-dimensional and spatial and compositionalsilhouette characteristics of each fragment of the historical settlement was evaluated.

The landscape-visual analysis, as well as cartographic and bibliographic studies, show rather high preservation of historical urban landscape and artistic value of panoramic views. Despite the losses associated with violation of successive development of the city in the XX-early XXI centuries, the main compositional features of the historical settlement were preserved. The safety of composition and the main component of the city composition (the silhouette of buildings, compositional and scenic connections in Vologda) is differentiated in different territories. The most valuable, preserving the integrity of panoramas and views, environmental elements are concentrated in the water area of the Vologda River. Here, despite the loss of some dominants, the preserved panoramas of historical buildings are crucial for the appearance of historical settlement. 
Historical and cultural landscapes, being the most important part of historical and cultural heritage, should be attributed to immovable monuments of history and culture, as modern society continues to transform the city territory, and its introduction into its structure is not always reasonable.

The amendments to the Federal Law "On Objects of Cultural Heritage (Historical and Cultural Monuments) of the Peoples of the Russian Federation" No. 73-FZ are truly revolutionary in the theory of urban planning. Understanding the value of settlement as a spatially integrated system of historical, cultural and natural territorial complexes, the importance of preserving the "sky contour" of panoramas and the conditions for their perception create prerequisites for precise formulation of protection subject of the historical settlement of Vologda. The high degree of preservation of threedimensional and spatial structure of the historical city, the value of its historical and cultural heritage determine the development potential for the historical settlement of Vologda and its attractiveness for the tourism business.

\section{References}

[1] Federal Law "On Objects of Cultural Heritage (Historical and Cultural Monuments) of the Peoples of the Russian Federation", dated 06.06.2002, 73-FZ (latest edition), 59, The concept of historical settlement.

[2] O.A. Zolotova, Cathedrals in the landscape and planning structure of city, Historical and local history almanac, Vologda, 4 (2003).

[3] I.P. Kukushkin,Vologda fortress of the second half of the XVI - XVII centuries, Antiquities of the North, Vologda (2016).

[4] M.V. Fehner, Vologda, Gosstroyizdat, Moscow(1959).

[5] Vologda in the past millennium: Essays on the history of the city, Antiquities of the North, Vologda (2004).

[6] S.A. Sharov,Development of planning and buildings of Vologda (XII-1613), Historical and architectural reference plan and the project of protection zones of historical and cultural monuments of the city of Vologda, II, part 2, VSRPO "Soyuzrestavratsiya", Moscow (1988). 